Article

\title{
Exploring the Chelating Potential of an Easily Synthesized Schiff Base for Copper Sensing
}

\author{
Jesús Sanmartín-Matalobos ${ }^{1, *(\mathbb{C})}$, Ana García-Deibe ${ }^{1} \mathbb{(}$, Morteza Zarepour-Jevinani ${ }^{1,2}$, \\ Manuel Aboal-Somoza ${ }^{3}$, Pilar Bermejo-Barrera ${ }^{3}$ and Matilde Fondo ${ }^{1}$ \\ 1 Coordination and Supramolecular Chemistry Group (Suprametal), Department of Inorganic Chemistry, \\ Faculty of Chemistry, Universidade de Santiago de Compostela, Avenida das Ciencias s/n, 15782 Santiago de \\ Compostela, Spain; ana.garcia.deibe@usc.es (A.G.-D.); mortezazarepourjevinani@gmail.com (M.Z.-J.); \\ matilde.fondo@usc.es (M.F.) \\ 2 Department of Chemistry, Sharif University of Technology, PO Box 11155-3516 Tehran, Iran \\ 3 Trace Element, Speciation and Spectroscopy Group (GETEE) - Health Research Institute of Santiago de \\ Compostela (IDIS), Strategic Grouping in Materials AEMAT, Department of Analytical Chemistry, Nutrition \\ and Bromatology, Faculty of Chemistry, Universidade de Santiago de Compostela, Avenida das Ciencias, s/n, \\ 15782 Santiago de Compostela, Spain; m.aboal@usc.es (M.A.-S.); pilar.bermejo@usc.es (P.B.-B.) \\ * Correspondence: jesus.sanmartin@usc.es
}

Received: 26 February 2020; Accepted: 21 March 2020; Published: 24 March 2020

check for updates

\begin{abstract}
The present study deals with the investigation of $\mathrm{Cu}^{2+}, \mathrm{Ni}^{2+}$ and $\mathrm{Pd}^{2+}$ chelating potential of the Schiff base, (E)-N-(2-((2-hydroxybenzylidene)amino)benzyl)-4-methylbenzenesulfonamide $\left(\mathrm{H}_{2} \mathrm{SB}\right)$. Crystal structures of $\mathrm{Ni}(\mathrm{HSB})_{2}, \mathrm{Pd}(\mathrm{HSB})_{2}$ and $\mathrm{Cu}(\mathrm{HSB})_{2}$ have been elucidated from single crystal X-ray diffraction data. NMR spectroscopy showed the presence of two conformers of $\mathrm{Pd}(\mathrm{HSB})_{2}$ in solution, both with an $E$ configuration of the ligand. The determination of binding constants by fluorescence quenching showed that affinity of $\mathrm{H}_{2} \mathrm{SB}$ to $\mathrm{Cu}^{2+}$ in solution is higher than for $\mathrm{Ni}^{2+}$ and $\mathrm{Pd}^{2+}$. Since there is a high demand for selective, sensitive, rapid and simple methods to detect copper in aqueous samples (both as $\mathrm{Cu}^{2+}$ ions and as $\mathrm{CuO}$ NPs), we have explored $\mathrm{H}_{2} \mathrm{SB}$ as an optical chemosensor. $\mathrm{H}_{2} \mathrm{SB}$ interacts with increasing concentrations of $\mathrm{Cu}^{2+}$ ions, giving rise to a linear increase in the absorbance of a band centered at about $392 \mathrm{~nm} . \mathrm{H}_{2} \mathrm{SB}$ displays a high selectivity toward $\mathrm{Cu}^{2+}$, even in the presence of the most common metal ions in water $\left(\mathrm{Ca}^{2+}, \mathrm{Mg}^{2+}, \mathrm{Na}^{+}, \mathrm{K}^{+}\right.$, $\mathrm{Al}^{3+}$ and $\mathrm{Fe}^{3+}$ ), and some heavy transition metal ions such as the soft acids $\mathrm{Pd}^{2+}$ and $\mathrm{Cd}^{2+} \cdot \mathrm{H}_{2} \mathrm{SB}$ also interacts with increasing concentrations of $\mathrm{CuO}$ NPs, which gives rise to a linear decrease in its fluorescence intensity $\left(\lambda_{\mathrm{em}}=500 \mathrm{~nm}, \lambda_{\mathrm{ex}}=390 \mathrm{~nm}\right)$. Quenching has occurred as a result of the formation of a non-fluorescent ground-state surface complex $\mathrm{H}_{2} \mathrm{SB}-\mathrm{CuO}$ NPs. The limits of detection and quantification of $\mathrm{CuO}$ NPs were $9.8 \mathrm{mg} / \mathrm{L}$ and $32.6 \mathrm{mg} / \mathrm{L}$, respectively. The presence of $\mathrm{TiO}_{2}$, $\mathrm{Ag}$ and $\mathrm{Au}$ NPs does not interfere with the determination of $\mathrm{CuO}$ NPs.
\end{abstract}

Keywords: X-ray; fluorescence; UV-Vis; CuO NPs; $\mathrm{Cu}^{2+}$ ions; Schiff base

\section{Introduction}

A number of methods for selective and highly sensitive detection of $\mathrm{Cu}^{2+}$ ions have been developed including, among others, inductively-coupled plasma mass spectrometry [1], electrochemical methods [2] and fluorescence spectroscopy [3-6]. However, these techniques frequently involve time-consuming sample pre-treatment methods and a need for sophisticated instrumentation and highly trained operators, precluding their routine application. This has stimulated the development of a variety of chemosensors based on absorption changes for the rapid and easy detection of $\mathrm{Cu}^{2+}$ ions [7-12]. Most of these reported colorimetric chemosensors have one or more of the following 
drawbacks: poor detection limit, long response time, tedious synthetic procedures, use of organic solvent or interference from other transition metal ions. Thus, a need exists for the exploration of new, simple and easy-to-make chemosensors based on absorption changes for detection of $\mathrm{Cu}^{2+}$ in aqueous solution.

Human and environmental health risks of $\mathrm{CuO}$ NPs are demanding affordable and reliable techniques for their detection [13-15]. This would increase safety related to the handling and release into the environment of NPs. Due to their selectivity, sensitivity and simplicity, chemical sensors such as fluorescent probes are very promising methods to be used not only for detection, but for quantification as well. Three fluorescent sensors have been developed for detection of Ag NPs [16-18], but investigation of optical sensors to detect and quantify $\mathrm{CuO}$ NPs remains virtually unexplored. Recently, we have reported a fluorescent probe for detecting $\mathrm{Cu}^{2+}$ ions in aqueous samples, as well as some preliminary studies for detecting CuO NPs [19].

We have chosen for our investigation the Schiff base (E)-N-(2-((2-hydroxybenzylidene) amino)benzyl)-4-methylbenzenesulfonamide, which will be abbreviated as $\mathrm{H}_{2} \mathrm{SB}$ (Figure 1). This ligand can be easily synthesized by reaction of the previously prepared $N$-(2-amino benzyl)-4-methylbenzenesulfonamide [20] with 2-hydroxybenzaldehyde, as we have previously reported [21]. We have found that $\mathrm{H}_{2} \mathrm{SB}$ can simultaneously bind two divalent ions through $\mu_{2}-N_{\text {sulfonamide }}$ bridges, allowing complexes of the type $\mathrm{M}_{2}(\mathrm{SB})_{2}$ to be obtained (where the dianionic $\mathrm{SB}^{2-}$ is acting as a tridentate ligand, and $\mathrm{M}$ is $\mathrm{Pd}^{2+}$ or $\mathrm{Cu}^{2+}[21]$. Now, the ligand can also behave as a monoanionic bidentate $\mathrm{O}, \mathrm{N}$-donor chelator, which also seems adequate to interact with the $\mathrm{CuO}$ surface due to its structural similarity with salicylate-type ligands. As the metal ion of a mineral surface acts as a Lewis acid and exchanges its coordinated hydroxyl groups with other ligands (ligand exchange), studying formation reactions of solution complexes will aid understanding of the interaction of anionic ligands with metal oxide surfaces. Keeping in mind that $\mathrm{H}_{2} \mathrm{SB}$ is a Lewis base with $\mathrm{N}$ and $\mathrm{O}$ donor atoms, this ligand may be suitable for binding to either hard, borderline or even soft acids, depending on circumstances. Hence, we have also studied its coordination behavior toward another borderline acid such as $\mathrm{Ni}^{2+}$, and a softer acid as $\mathrm{Pd}^{2+}$. Therefore, we have investigated the formation of the solution complexes $\mathrm{Cu}(\mathrm{HSB})_{2}, \mathrm{Ni}(\mathrm{HSB})_{2}$ and $\mathrm{Pd}(\mathrm{HSB})_{2}$ using a combination of UV-Vis, FT-IR, NMR and fluorescence spectrometry as well as elemental analysis and $\mathrm{X}$-ray diffraction. Then, we have investigated changes in the UV-Vis absorbance and fluorescence spectra of $\mathrm{H}_{2} \mathrm{SB}$ upon titration with $\mathrm{Cu}^{2+}$ and $\mathrm{CuO}$ NPs, respectively, also in comparison with other common metal species in water.
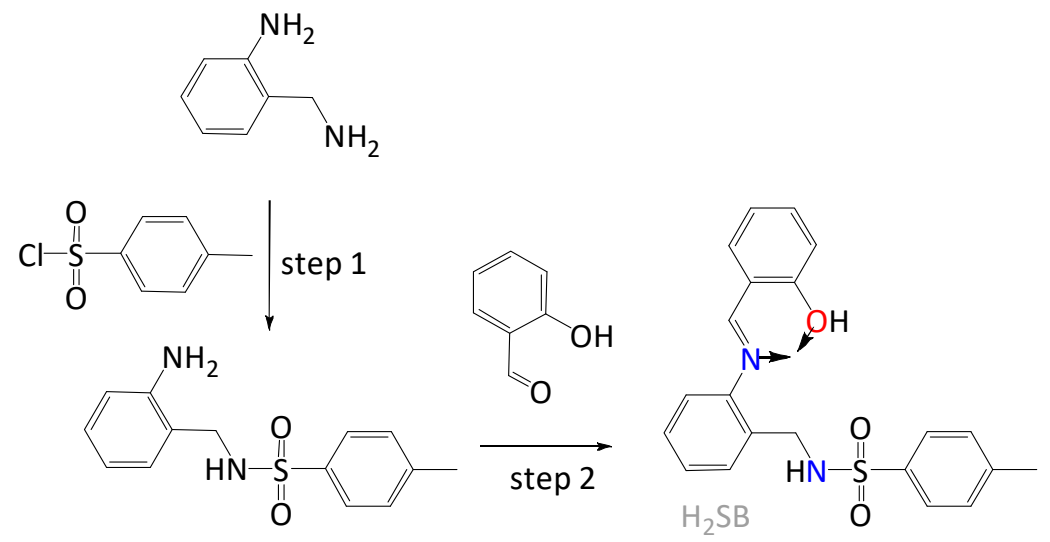

Figure 1. Schematic representation of the easy synthesis of (E)-N-(2-((2-hydroxybenzylidene)amino) benzyl)-4-methylbenzenesulfonamide $\left(\mathrm{H}_{2} \mathrm{SB}\right)$ with the metal binding site indicated by arrows. 


\section{Experimental}

\subsection{Materials and Methods}

The reagents and starting materials were commercially available, and used without further purification. The synthesis of $\mathrm{H}_{2} \mathrm{SB}$ (Figure 1) has been previously reported [20,21]. Infrared spectra were recorded as $\mathrm{KBr}$ pellets on a Jasco FT/IR-410 spectrophotometer in the range $4000-600 \mathrm{~cm}^{-1}$. Elemental analyses were performed on a Carlo Erba EA 1108 analyzer. The UV-Vis spectra were performed on a Uvikon 810 spectrophotometer (Kontron Instruments) using a methanol-water solution (in 80:20 v/v) as solvent. ${ }^{1} \mathrm{H}$ NMR spectra $\left(400 \mathrm{MHz}\right.$ ) were measured in dmso- $d_{6}$. NMR assignments were carried out by a combination of COSY and NOESY experiments. In order to simplify, the NMR numbering scheme is equivalent to that shown for the molecular structures of $\mathrm{Ni}(\mathrm{HSB})_{2}, \mathrm{Pd}(\mathrm{HSB})_{2}$ and $\mathrm{Cu}(\mathrm{HSB})_{2}$.

\subsection{Crystal Structure Analysis Data}

Diffraction data for $\mathrm{Ni}(\mathrm{HSB})_{2}, \mathrm{Pd}(\mathrm{HSB})_{2} \mathrm{Cu}(\mathrm{HSB})_{2}$ were collected at $100(2) \mathrm{K}$, using graphitemonochromatized Mo-K $\alpha$ radiation $(\lambda=0.71073 \AA$ ). Some significant refinement data and crystal parameters are summarized in Table S1. Data were corrected for polarization and Lorentz effects, while multi-scan absorption corrections were performed with SADABS [22]. The structures were solved by standard direct methods [23], and then refined by full matrix least squares on $F^{2}$ [24]. All non-hydrogen atoms were anisotropically treated. Hydrogen atoms were included in the structure factor calculation, by using a riding model, with thermal parameters depending on the parent atom in geometrically idealized positions.

\subsection{Synthesis of $P d(H S B)_{2}$}

A methanol solution $(40 \mathrm{~mL})$ of $\mathrm{H}_{2} \mathrm{SB}(0.15 \mathrm{~g}, 0.39 \mathrm{mmol})$ and $\mathrm{Pd}(\mathrm{OAc})_{2} \cdot 4 \mathrm{H}_{2} \mathrm{O}(0.05 \mathrm{~g}, 0.18 \mathrm{mmol})$ was stirred for $4 \mathrm{~h}$ at room temperature. The resulting orange precipitate was filtered off, washed with methanol and then dried under vacuum. Yield $=0.15 \mathrm{~g}(86 \%)$. Prismatic orange crystals of $\mathrm{Pd}(\mathrm{HSB})_{2}$ suitable for single-crystal X-ray studies were obtained by recrystallization in acetone.

\subsection{Synthesis of $\mathrm{Ni}(\mathrm{HSB})_{2}$}

A methanol solution $(40 \mathrm{~mL})$ of $\mathrm{H}_{2} \mathrm{SB}(0.10 \mathrm{~g}, 0.26 \mathrm{mmol})$ and $\mathrm{Ni}(\mathrm{OAc})_{2} \cdot 4 \mathrm{H}_{2} \mathrm{O}(0.04 \mathrm{~g}, 0.13 \mathrm{mmol})$ was stirred for $4 \mathrm{~h}$ at room temperature. The resulting green precipitate was filtered off, washed with cooled methanol and then dried under vacuum. Yield $=0.07 \mathrm{~g}(70 \%)$. Rhombic green crystals of $\mathrm{Ni}(\mathrm{HSB})_{2}$ suitable for single-crystal X-ray studies were obtained by recrystallization in methanol.

\subsection{Synthesis of $\mathrm{Cu}(\mathrm{HSB})_{2}$}

A methanol solution $(40 \mathrm{~mL})$ of $\mathrm{H}_{2} \mathrm{SB}(0.10 \mathrm{~g}, 0.26 \mathrm{mmol})$ and $\mathrm{Cu}(\mathrm{OAc})_{2} \cdot \mathrm{H}_{2} \mathrm{O}(0.03 \mathrm{~g}, 0.13 \mathrm{mmol})$ was stirred for $4 \mathrm{~h}$ at room temperature. The resulting green precipitate was filtered off, washed with cooled methanol and then dried under vacuum. Yield $=0.08 \mathrm{~g}(75 \%)$. Rhombic green crystals of $\mathrm{Cu}(\mathrm{HSB})_{2}$ obtained by recrystallization in methanol were suitable for single-crystal X-ray studies.

\section{Results and Discussion}

In contrast with the previously reported dianionic tridentate $\mathrm{O}, \mathrm{N}, \mathrm{N}$-donor behavior of the ligand [21], now we have achieved that this ligand can also behave as a monoanionic bidentate $\mathrm{O}, \mathrm{N}$-donor chelating agent. This is due to the use of softer reaction conditions, i.e., room temperature instead of reflux temperature, and with a 1:2 metal-ligand ratio, instead of the formerly used 1:1 ratio. 


\subsection{Crystal Structures of $\mathrm{Pd}(\mathrm{HSB})_{2}, \mathrm{Ni}(\mathrm{HSB})_{2}$ and $\mathrm{Cu}(\mathrm{HSB})_{2}$}

Single crystal X-ray diffraction techniques have shown that the asymmetric unit only contains half a complex, with the metal ion (i.e., $\mathrm{Pd}^{2+}, \mathrm{Ni}^{2+}$ or $\mathrm{Cu}^{2+}$ ) sited on an inversion center, so that the other half is generated by symmetry. The coordination environment of the metal ion can be qualified as a slightly distorted square, formed by the $O, N$-chelating binding domains of both ligand units, with bite angles of ca. $90.5^{\circ}$, while the whole chromophore is absolutely planar, including the central metal ion. The loss of conjugation of the phenyl ring corresponding to the diamine residue (C8-C13), in relation to the salicylaldimine aromatic system (C14-C20) should be mentioned, since their respective planes form a wide angle of ca. $75.7^{\circ}$. The main angles and bond distances are collected in Tables S2-S4.

The molecular structure of $\mathrm{Cu}(\mathrm{HSB})_{2}$, which is represented in Figure 2 (top), shows a trans disposition of the $\mathrm{N}$ and $\mathrm{O}$ donor atoms related to both salicylaldehyde residues. This appears to be favored by both intramolecular $\mathrm{N}-\mathrm{H} \cdots \mathrm{O}$ interactions between sulfonamide and phenoxo groups (about $2.9 \AA$ ), as well as by the significant steric hindrance that the diamine residue and the uncoordinated tosyl groups can exert. Tosyl groups show an anti-conformation, as they are positioned at opposite sides of the plane formed by the $\mathrm{CuN}_{2} \mathrm{O}_{2}$ chromophore. With this spatial arrangement their tosyl rings (C1-C6) are stacked with those of their corresponding salicylaldimine residues (C15-C20), with a distance between their respective centroids of ca. $4.15 \AA$. Neighboring neutral complex molecules are not interacting via classic $\mathrm{H}$ bonds, but the packing scheme is mostly based on $\mathrm{C}-\mathrm{H} \cdots \mathrm{O}$ interactions between aromatic $\mathrm{H}$ atoms and one of $\mathrm{O}$ atoms of the tosyl groups, as well as on $\pi-\pi$ stacking interactions between the phenyl rings of the diamine residues.

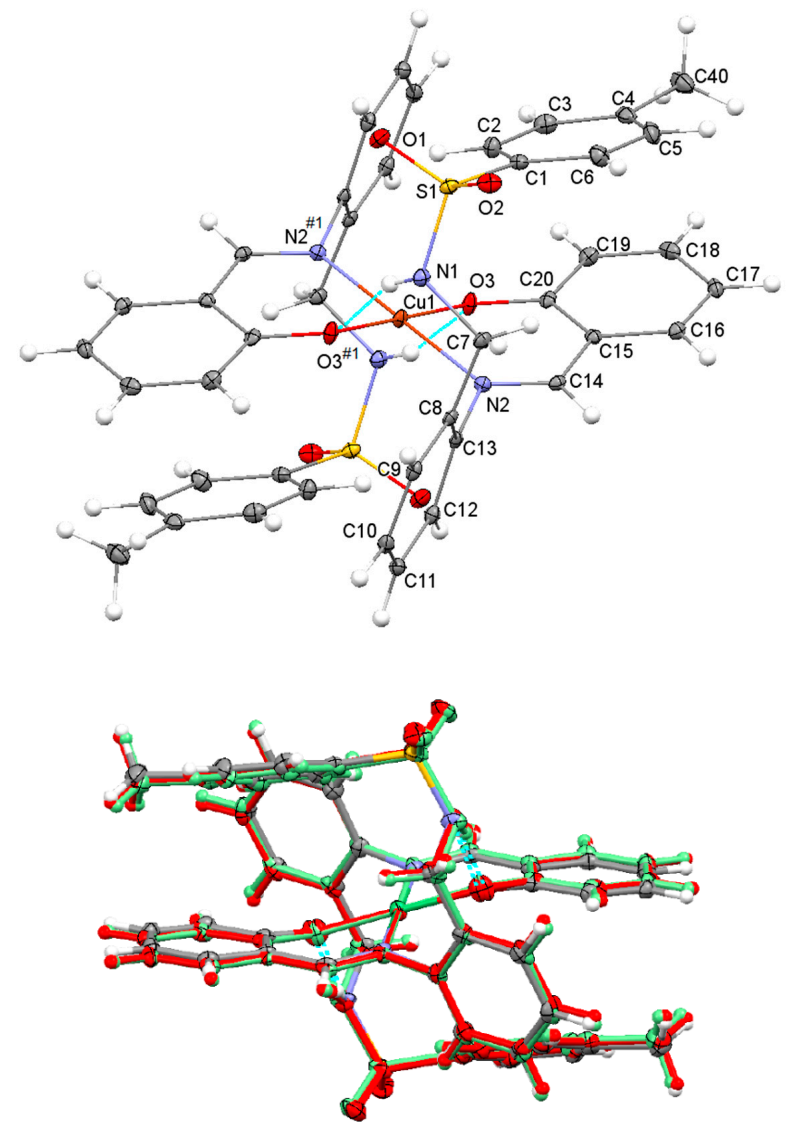

Figure 2. Top: Ellipsoid view of the molecular structure of $\mathrm{Cu}(\mathrm{HSB})_{2}$ with intramolecular $\mathrm{N}-\mathrm{H} \cdots \mathrm{O}$ interactions (only labels for the asymmetric unit, jointly with the donor atoms N2 and O3 generated by symmetry have been included). Bottom: Overlay of the molecular structures of $\mathrm{Ni}(\mathrm{HSB})_{2}$ (in standard colors), $\mathrm{Pd}(\mathrm{HSB})_{2}$ (in red color) and $\mathrm{Cu}(\mathrm{HSB})_{2}$ (in green color). 
The great coincidence between the molecular structures of $\mathrm{Cu}(\mathrm{HSB})_{2}, \mathrm{Pd}(\mathrm{HSB})_{2}$ and $\mathrm{Ni}(\mathrm{HSB})_{2}$ seems to indicate that the spatial arrangement observed for the complex in the solid state must be highly favored (Figure 2, bottom). The molecular structures of $\mathrm{Pd}(\mathrm{HSB})_{2}$ and $\mathrm{Ni}(\mathrm{HSB})_{2}$ are shown in supplementary material (Figures S1 and S2), while their geometric parameters are also collected in the supplementary information (Tables S2 and S3).

\subsection{Spectroscopic Characterisation of $\mathrm{Pd}(\mathrm{HSB})_{2}, \mathrm{Ni}(\mathrm{HSB})_{2}$ and $\mathrm{Cu}(\mathrm{HSB})_{2}$}

Elemental analysis data and spectroscopic data, obtained from FT-IR, UV-Vis and ${ }^{1} \mathrm{H}$ NMR spectrometry, were as follows.

$\operatorname{Pd}(\mathrm{HSB})_{2}:{ }^{1} \mathrm{H}$ NMR $\left(500 \mathrm{MHz}, \mathrm{dmso}_{6}, \delta\right.$ in ppm): 7.89 (s, 2H, H14), 7.88 (s, 2H, H14'), 7.79 (t, $\left.2 \mathrm{H}, \mathrm{HN}^{\prime}\right), 7.69(\mathrm{t}, 2 \mathrm{H}, \mathrm{HN}), 7.51(\mathrm{~d}, 4 \mathrm{H}, \mathrm{H} 2+\mathrm{H} 6), 7.43\left(\mathrm{~d}, 4 \mathrm{H}, \mathrm{H} 2^{\prime}+\mathrm{H}^{\prime}\right), 7.39(\mathrm{~d}, 2 \mathrm{H}, \mathrm{H} 9), 7.34(\mathrm{t}, 2 \mathrm{H}$, H11), 7.30 (d, 2H, H16), 7.15 (t, 2H, H18), 7.05 (d, 4H, H3 + H5), $6.92\left(\mathrm{~d}, 4 \mathrm{H}, \mathrm{H} 3^{\prime}+\mathrm{H} 5^{\prime}\right), 6.52(\mathrm{t}, 2 \mathrm{H}$,

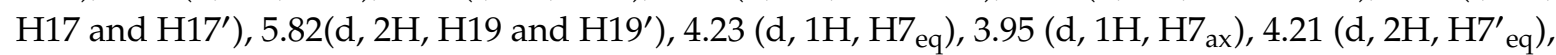
$3.86\left(\mathrm{~d}, 2 \mathrm{H}, \mathrm{H}^{\prime}{ }_{\mathrm{ax}}\right), 2.18$ (s, 6H, H40 and H40'). UV-Vis ( $\lambda$ in nm): 210, 226, 270, 336. IR $\left(\mathrm{KBr}, v\right.$ in cm $\left.{ }^{-1}\right)$ : $v(\mathrm{NH}) 3272, v\left(\mathrm{C}=\mathrm{N}_{\text {imine }}\right) 1609, v_{\text {as }}\left(\mathrm{SO}_{2}\right) 1320, v_{\mathrm{s}}\left(\mathrm{SO}_{2}\right)$ 1158. Elemental analysis (found): $\mathrm{C} 58.3 ; \mathrm{H} 4.3$; $\mathrm{N}$ 6.3; $\mathrm{S} 7.2 \%$; calc. for $\mathrm{C}_{42} \mathrm{H}_{38} \mathrm{~N}_{4} \mathrm{O}_{6} \mathrm{PdS}_{2}$ : C 58.3; $\mathrm{H} 4.4 ; \mathrm{N} 6.5 ; \mathrm{S} 7.4 \%$.

$\mathrm{Ni}(\mathrm{HSB})_{2}$ : UV-Vis $\left(\lambda\right.$ in nm): 204, 230, 268, 392. IR $\left(\mathrm{KBr}, v\right.$ in $\left.\mathrm{cm}^{-1}\right): v(\mathrm{NH}) 3270, v\left(\mathrm{C}=\mathrm{N}_{\text {imine }}\right)$ $1608, v_{\mathrm{as}}\left(\mathrm{SO}_{2}\right) 1318, v_{\mathrm{s}}\left(\mathrm{SO}_{2}\right)$ 1160. Elemental analysis (found): $\mathrm{C} 61.8 ; \mathrm{H} 4.7 ; \mathrm{N} 6.8 ; \mathrm{S} 7.8 \%$; calc. for $\mathrm{C}_{42} \mathrm{H}_{38} \mathrm{~N}_{4} \mathrm{NiO}_{6} \mathrm{~S}_{2}$ : C, 61.7; $\mathrm{H}, 4.7 ; \mathrm{N}, 6.9 ; \mathrm{S} 7.8 \%$.

$\mathrm{Cu}(\mathrm{HSB})_{2}$ : UV-Vis $\left(\lambda\right.$ in nm): 206, 230, 288, 392. IR (KBr, $v$ in $\left.\mathrm{cm}^{-1}\right): v(\mathrm{NH}) 3271, v\left(\mathrm{C}=\mathrm{N}_{\text {imine }}\right)$ $1585, v_{\mathrm{as}}\left(\mathrm{SO}_{2}\right)$ 1327, $v_{\mathrm{s}}\left(\mathrm{SO}_{2}\right)$ 1156. Elemental analysis (found): $\mathrm{C} 61.3 ; \mathrm{H} 4.7 ; \mathrm{N} 6.7 ; \mathrm{S} 7.7 \%$; calc. for $\mathrm{C}_{42} \mathrm{H}_{38} \mathrm{CuN}_{4} \mathrm{O}_{6} \mathrm{~S}_{2}$ : C 61.3; $\mathrm{H} 4.7 ; \mathrm{N}$ 6.8; $\mathrm{S} 7.8 \%$.

\subsubsection{NMR Study of $\mathrm{Pd}(\mathrm{HSB})_{2}$}

The molecular structure of $\mathrm{Pd}(\mathrm{HSB})_{2}$ in solution has been investigated by $1 \mathrm{D}\left({ }^{1} \mathrm{H}\right.$ experiment $)$ and 2D (COSY and NOESY experiments) NMR spectroscopy. The diamagnetic nature of $\mathrm{Pd}(\mathrm{HSB})_{2}$ indicates a square planar environment around the $\mathrm{Pd}^{2+}$ ion. The 2D COSY spectrum (Figure S3) allowed us an assignment of the signals with very few shadows, crucial for this study.

The ${ }^{1} \mathrm{H}$ NMR spectrum shows a shift of about $0.8 \mathrm{ppm}$ to the high field of the signal corresponding to the $-\mathrm{CH}=\mathrm{N}$ group, which was observed at $8.7 \mathrm{ppm}$ in the free ligand (Figure 3), indicating that the imino group is coordinated to the palladium(II) ion through the lone pair of its nitrogen atom. The absence of the $\mathrm{OH}$ signal, as well as the presence of the $\mathrm{NH}$ signal, suggests that the ligand is coordinated as a monoanionic species. The clear observation of two sets of signals for both sulfonamide $(\mathrm{NH})$ and methylene protons (H-7) is a clear sign of the presence of two conformational isomers. Each one of these isomers could be stabilized by intramolecular $\mathrm{N}-\mathrm{H} \cdots \mathrm{O}$ and $\mathrm{N}-\mathrm{H} \cdots \mathrm{N}$ interactions, preventing its interconversion by rotations around $\mathrm{C}-\mathrm{N}$ single bonds.

The 2D NOESY spectrum of $\mathrm{Pd}(\mathrm{HSB})_{2}$ shows cross peaks due to the coupling of the imine proton (H-14) with aromatic protons $\mathrm{H}-12$ and $\mathrm{H}-16$ (Figure 4), which is indicative of an E configuration in solution. The coupling of the aromatic proton $\mathrm{H}-9$ with methylene protons (H-7) evidences the diastereotopic nature of the latter ones (with signals at about $3.9 \mathrm{ppm}$ and $4.2 \mathrm{ppm}$ ). 


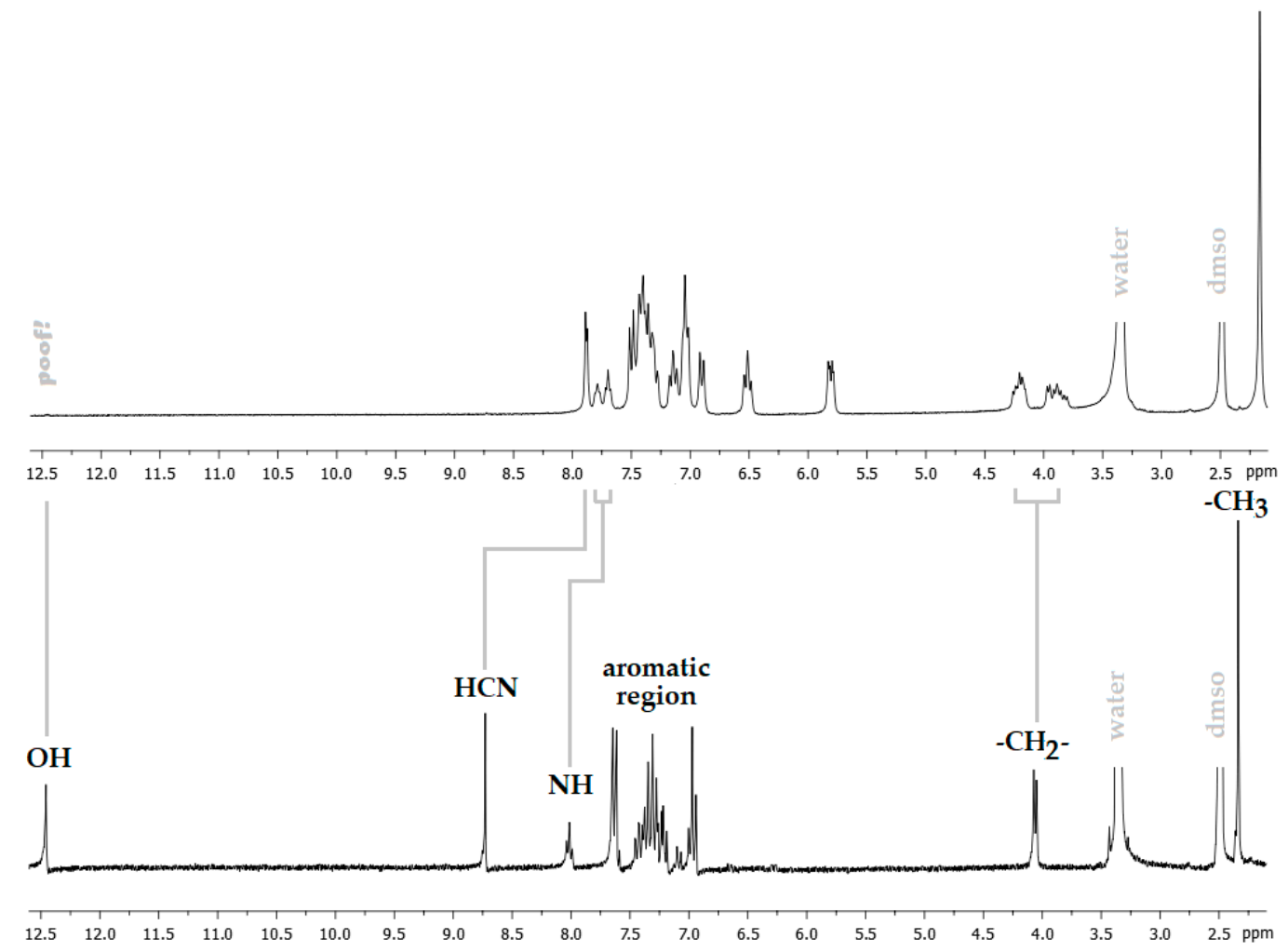

Figure 3. View of the ${ }^{1} \mathrm{H}$ NMR spectra of $\mathrm{Pd}(\mathrm{HSB})_{2}$ (top) and $\mathrm{H}_{2} \mathrm{BS}$ (bottom).

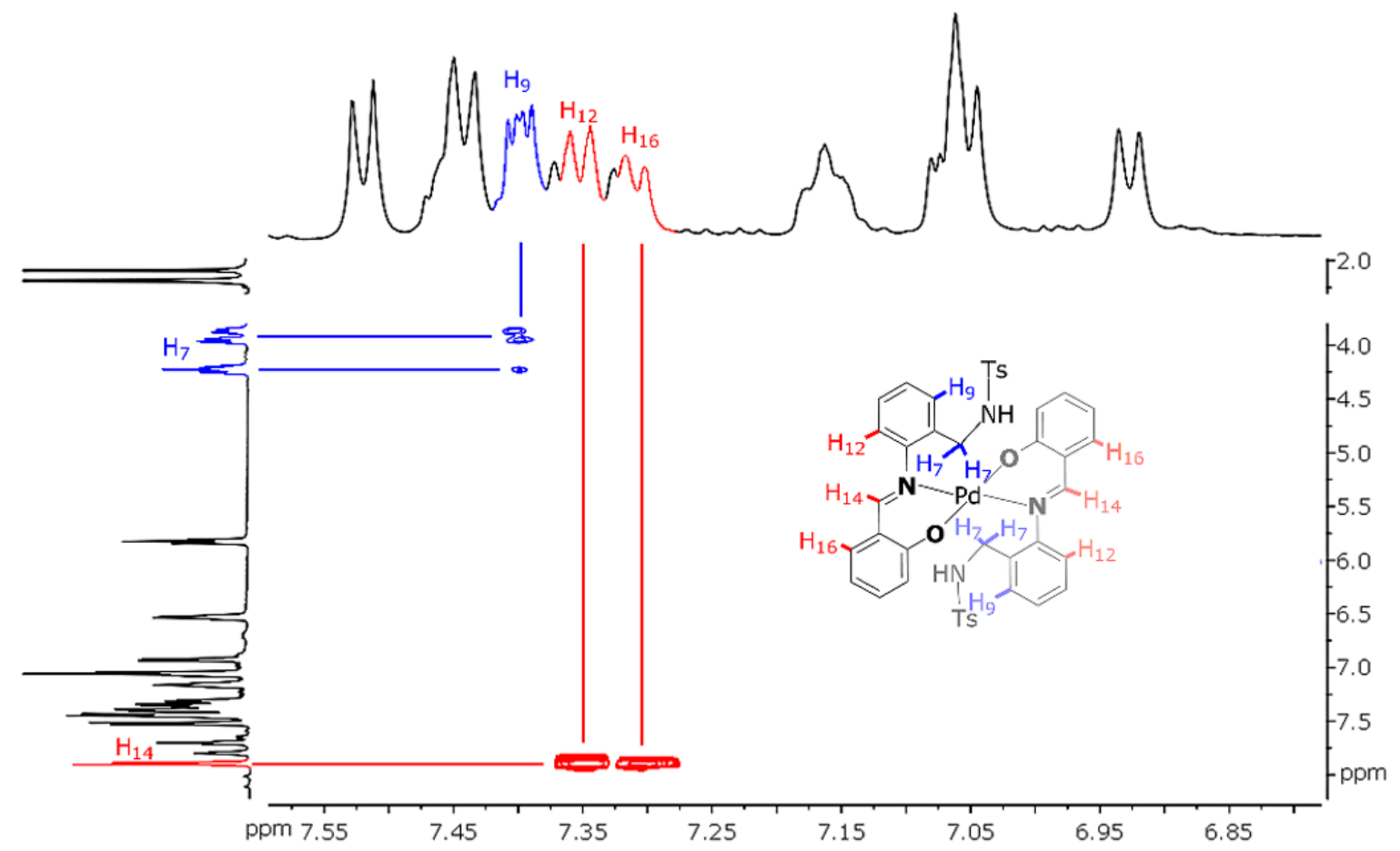

Figure 4. View of the NOESY spectrum of $\mathrm{Pd}(\mathrm{HSB})_{2}$ (in dmso- $\left.d_{6}\right)$, with schematic representation of the metal complex (inset). 


\subsubsection{UV-Vis Absorption Study of $\mathrm{Pd}(\mathrm{HSB})_{2}, \mathrm{Ni}(\mathrm{HSB})_{2}$ and $\mathrm{Cu}(\mathrm{HSB})_{2}$}

The most remarkable spectral change observed is that complexation of $\mathrm{H}_{2} \mathrm{SB}$ with $\mathrm{Cu}^{2+}$ and $\mathrm{Ni}^{2+}$ (but not with $\mathrm{Pd}^{2+}$ ) gives rise to a new absorption band at about $392 \mathrm{~nm}$, which was assigned to a metal-to-ligand charge transfer (MLTC). In order to explore the ability of $\mathrm{H}_{2} \mathrm{SB}$ to perform as a colorimetric chemosensor for detection of $\mathrm{Cu}^{2+}$ ions, we have paid special attention to changes on the cited MLTC absorption band.

The UV-Vis spectrum of $\mathrm{Cu}(\mathrm{HSB})_{2}$ clearly shows that the $\mathrm{n} \rightarrow \pi^{*}$ transition attributable to the imino group [25] underwent a red (bathochromic) shift from 270 to $285 \mathrm{~nm}$, as a result of coordination (Figure 5). This is due to a remarkable increase in the electron density at the imine nitrogen atom, as a consequence of the $\mathrm{Cu}^{2+}$ complexation. By contrast, no change on the wavelength of the $\mathrm{n} \rightarrow \pi^{*}$ transitions attributable to the imino group were detected in the spectra of $\mathrm{Pd}(\mathrm{HSB})_{2}$ and $\mathrm{Ni}(\mathrm{HSB})_{2}$. As this could be related to the strength of the $\mathrm{M}-\mathrm{N}$ bond $\left(\mathrm{M}=\mathrm{Pd}^{2+}, \mathrm{Ni}^{2+}\right.$ or $\left.\mathrm{Cu}^{2+}\right)$, we have measured the binding constants of $\mathrm{Pd}(\mathrm{HSB})_{2}, \mathrm{Ni}(\mathrm{HSB})_{2}$ and $\mathrm{Cu}(\mathrm{HSB})_{2}$. Benesi-Hildebrand equation [26] was used for determining the binding constant based on fluorescence spectra (Figure S4). The values of the binding constant $\left(\mathrm{K}_{\mathrm{b}}\right)$ of $\mathrm{H}_{2} \mathrm{SB}$ with $\mathrm{Pd}^{2+}, \mathrm{Ni}^{2+}$ and $\mathrm{Cu}^{2+}$ in $2: 1$ molar ratio, were found to be about $1.9210^{3} \mathrm{M}^{-1}, 3.5410^{3} \mathrm{M}^{-1}$ and $4.7310^{3} \mathrm{M}^{-1}$, respectively. Thus, the binding affinity of $\mathrm{H}_{2} \mathrm{SB}$ to $\mathrm{Cu}^{2+}$ in solution is higher than that found for $\mathrm{Ni}^{2+}$ and $\mathrm{Pd}^{2+}$.

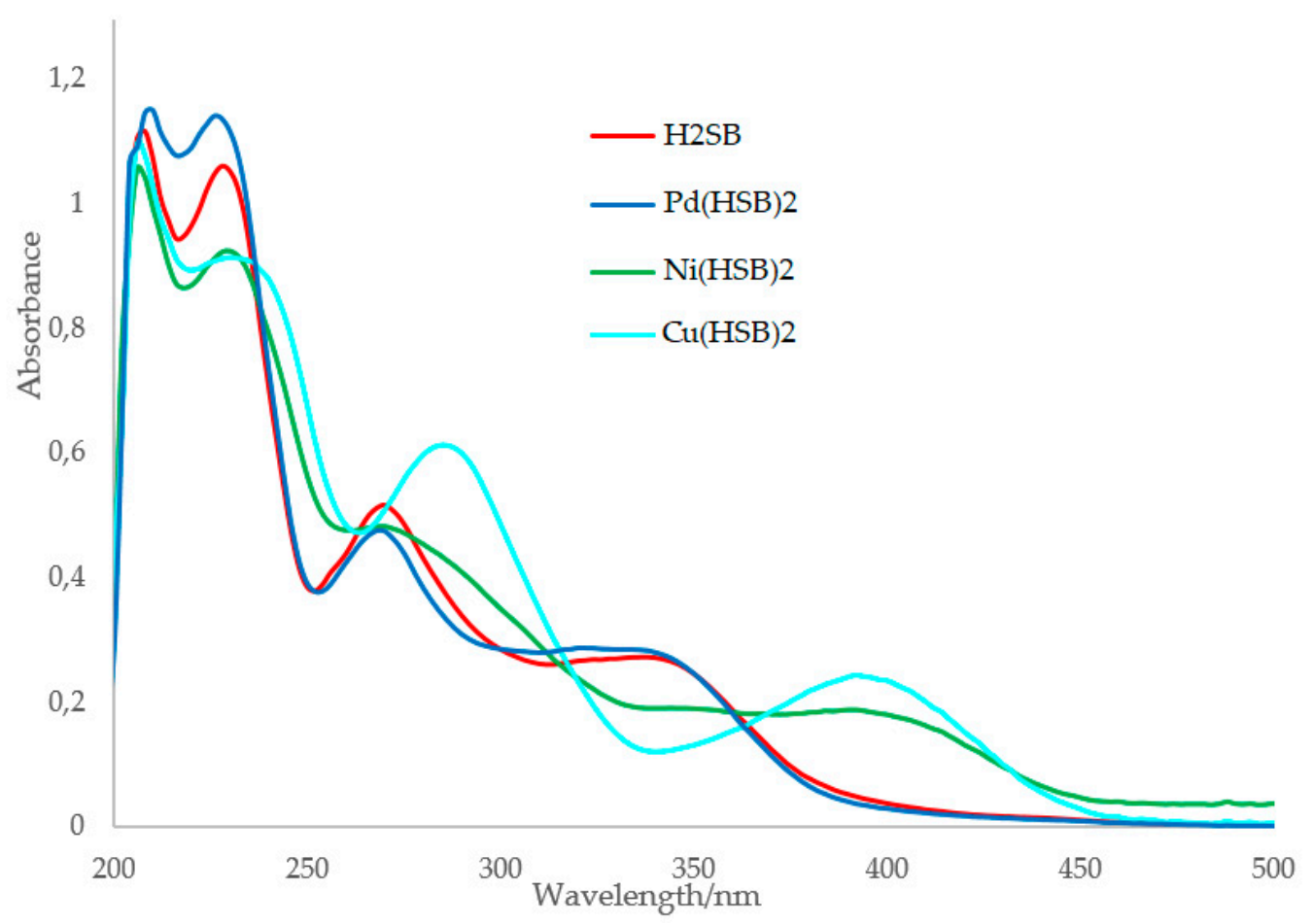

Figure 5. Absorption spectra of $\mathrm{H}_{2} \mathrm{SB}, \mathrm{Pd}(\mathrm{HSB})_{2}, \mathrm{Ni}(\mathrm{HSB}) 2$ and $\mathrm{Cu}(\mathrm{HSB}) 2$ using a methanol-water solution as solvent (in 80:20 v/v).

\subsection{Absorption Studies on the $\mathrm{H}_{2} \mathrm{SB}-\mathrm{Cu}^{2+}$ Interaction}

With the aim of studying the enhancement of the absorbance intensity at $392 \mathrm{~nm}$ with increasing $\mathrm{Cu}^{2+}$ ion concentration, spectral data were recorded after addition of an increasing volume of $\mathrm{Cu}(\mathrm{OAc})_{2} \cdot \mathrm{H}_{2} \mathrm{O}$ at concentration $100 \mu \mathrm{M}(0.0 \mathrm{~mL}, 0.1 \mathrm{~mL}, 0.2 \mathrm{~mL}, 0.3 \mathrm{~mL}, 0.4 \mathrm{~mL}, 0.5 \mathrm{~mL}, 0.6 \mathrm{~mL}, 0.7$ $\mathrm{mL}, 0.8 \mathrm{~mL}, 0.9 \mathrm{~mL}$ and $1.0 \mathrm{~mL})$ to $\mathrm{H}_{2} \mathrm{SB}$ at concentration $100 \mu \mathrm{M}(1.0 \mathrm{~mL})$. Results showed that the absorbance of the MLTC band linearly varied with increasing concentrations of $\mathrm{Cu}^{2+}$ in the range 0-2.1 $\mathrm{mg} / \mathrm{L}(33.33 \mu \mathrm{M})$, tripling its initial value (Figure 6). 


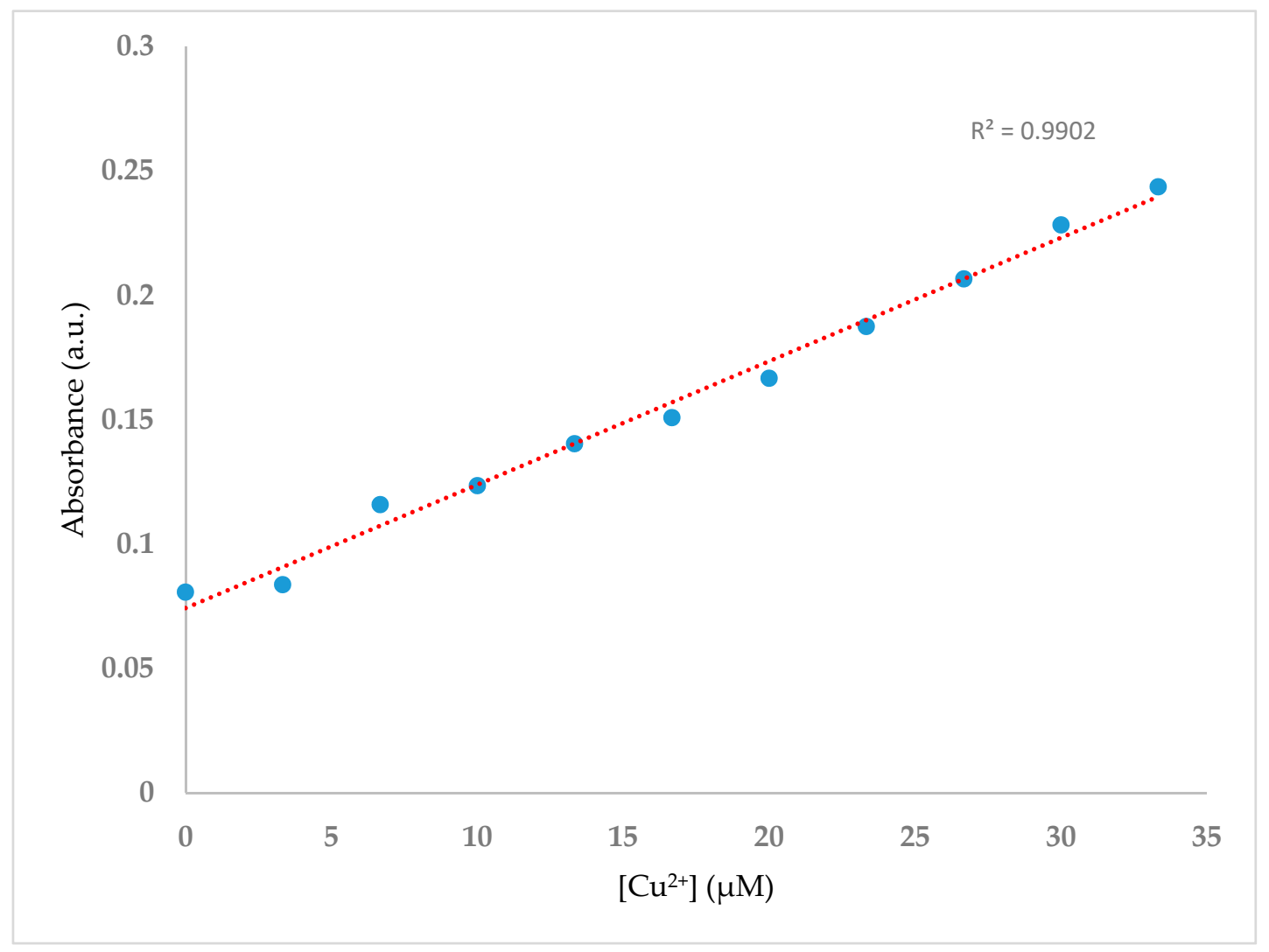

Figure 6. UV-Vis titration spectra of $\mathrm{H}_{2} \mathrm{SB}(100 \mu \mathrm{M})$ in methanol-water mixture $(80: 20 \mathrm{v} / \mathrm{v})$ at room temperature and neutral $\mathrm{pH}$, upon sequential addition of $\mathrm{Cu}^{2+}(0-1$ equiv).

The selectivity of $\mathrm{H}_{2} \mathrm{SB}$ for $\mathrm{Cu}^{2+}$ ions was examined by testing the response of the $\mathrm{H}_{2} \mathrm{SB}$ to some other metal ions, including some common ions in water, such as $\mathrm{Na}^{+}, \mathrm{K}^{+}, \mathrm{Ca}^{2+}, \mathrm{Mg}^{2+}, \mathrm{Al}^{3+}$ and $\mathrm{Fe}^{3+}$, and some heavy metal ions, such as some borderline acids $\left(\mathrm{Ni}^{2+}, \mathrm{Co}^{2+}\right.$ and $\left.\mathrm{Zn}^{2+}\right)$, as well as some other soft acids $\left(\mathrm{Pd}^{2+}\right.$ and $\left.\mathrm{Cd}^{2+}\right)$. By comparison, no increase of the absorbance at $392 \mathrm{~nm}$ similar to that displayed in the $\mathrm{H}_{2} \mathrm{SB}-\mathrm{Cu}^{2+}$ system was observed upon the addition of $\mathrm{Na}^{+}, \mathrm{K}^{+}, \mathrm{Ca}^{2+}, \mathrm{Mg}^{2+}$, $\mathrm{Al}^{3+}, \mathrm{Fe}^{3+}, \mathrm{Pd}^{2+}$ and $\mathrm{Cd}^{2+}$ ions), suggesting that $\mathrm{H}_{2} \mathrm{SB}$ could potentially be used to detect $\mathrm{Cu}^{2+}$ ions in a sample matrix containing both hard and soft metal ions. The addition of other borderline acids such as $\mathrm{Ni}^{2+}, \mathrm{Co}^{2+}$ and $\mathrm{Zn}^{2+}$ ions to a solution of $\mathrm{H}_{2} \mathrm{SB}$ in 1:1 molar ratio results in an increase of the absorbance at $392 \mathrm{~nm}(23 \%, 39 \%$ and $85 \%$, respectively. Therefore, these borderline acids could interfere in the determination of $\mathrm{Cu}^{2+}$ ions, which led us to abandon the exploration of the ability of $\mathrm{H}_{2} \mathrm{SB}$ to function as an absorption chemosensor for detection of $\mathrm{Cu}^{2+}$ ions.

\subsection{Fluorescence Studies on the Interaction of $\mathrm{H}_{2} \mathrm{SB}$ with $\mathrm{CuO} N P S$}

Good results in fluorescence studies on the interaction $\mathrm{H}_{2} \mathrm{SB}-\mathrm{Cu}^{2+}$ [21] encouraged us to extend our investigations to the interaction of $\mathrm{H}_{2} \mathrm{SB}$ with $\mathrm{CuO}$ NPs. We have speculated that $\mathrm{Cu}^{2+}$ ions in the oxide lattice can form inner-sphere surface complexes of $\mathrm{HSB}^{-}$by ligand exchange in a way similar to that occurring in solution. It is known that, since $\mathrm{O}^{2-}$ and $\mathrm{Cu}^{2+}$ ions at $\mathrm{CuO}$ NPs' surface are incompletely coordinated, they have partial charges. Consequently, CuO NPs immersed in water attract and bind water molecules on their surfaces, and the subsequent dissociation of these surface water molecules leaves hydroxyl groups bound to the surface $\mathrm{Cu}^{2+}$ ions, releasing of hydron cations. Similarly, incompletely coordinated $\mathrm{O}^{2-}$ can react with water to leave surface hydroxyl groups, releasing hydroxyl anions. Therefore, the surface of nanoparticles quickly becomes covered with hydroxyl groups, and hence, surface hydroxyl groups can act as proton acceptors, leading to more exchangeable ligands. Monodeprotonated $\mathrm{HSB}^{-}$may be absorbed by replacement of a surface $\mathrm{OH}$ 
group (ligand exchange) giving inner-sphere complexes and releasing water (Figure 7). Among the six typical interaction mechanisms between NPs and dissolved organic matter (hydrophobic interaction, electrostatic and van de Waals interactions, ligand exchange, chelation, cation bridging and H-bonding), ligand exchange was reported as the dominant mechanism accounting for sorption of dissolved organic matter on metal oxide NPs $[27,28]$.

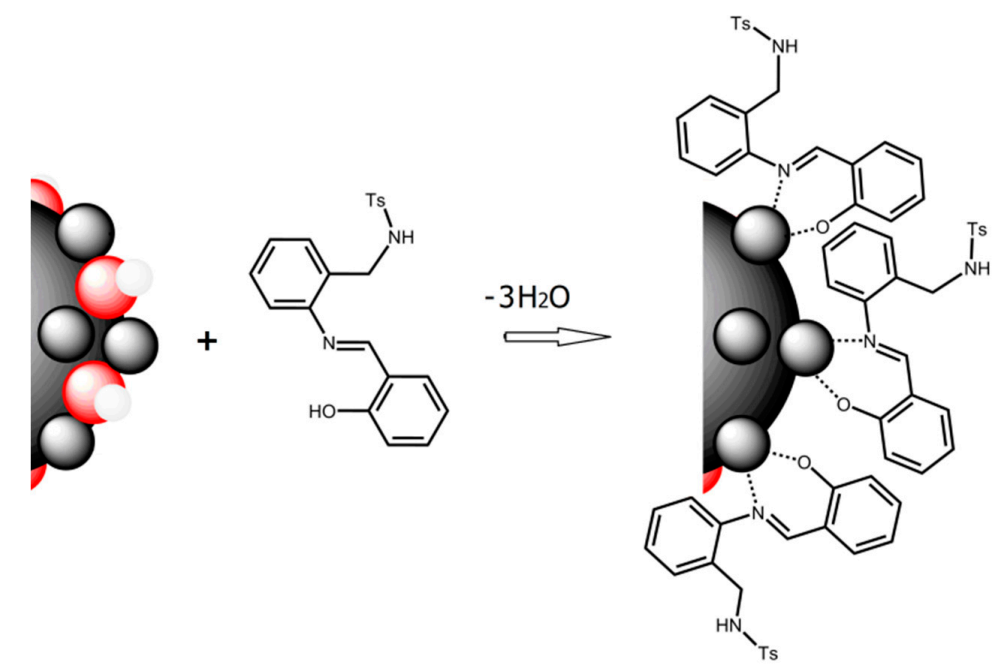

Figure 7. Schematic description of ligand exchange, which is the proposed sorption mechanism of $\mathrm{H}_{2} \mathrm{SB}$ (acting as bidentate chelating ligand) on the surfaces of $\mathrm{CuO} \mathrm{NPs}\left(\mathrm{Cu}^{2+}\right.$ ions are in grey and $\mathrm{O}^{2-}$ are in red).

To gain a better understanding of the favorable conditions under which binding of $\mathrm{H}_{2} \mathrm{SB}$ on $\mathrm{CuO}$ NPs surfaces could occur, the effect of $\mathrm{pH}$ on the surface charge of $\mathrm{CuO}$ NPs has been analyzed (Figure 8). We have found that the $\mathrm{pH}$ of zero point of charge $\left(\mathrm{pH}_{\mathrm{zpc}}\right)$ of $\mathrm{CuO}$ NPs is 6.0, and therefore, a $\mathrm{pH}$ value in the range 7.0-7.5 could be adequate to form surface complexes $\mathrm{H}_{2} \mathrm{SB}-\mathrm{CuO}$ NPs. Since it is expected that adsorption of $\mathrm{H}_{2} \mathrm{SB}$ on the negatively charged $\mathrm{CuO}$ NPs decreases with increasing $\mathrm{pH}$, we have investigated variations in fluorescence intensity of $\mathrm{H}_{2} \mathrm{SB}$ with concentration of $\mathrm{CuO}$ $\mathrm{NPs}$ at near-neutral $\mathrm{pH}$ values, so the addition of $\mathrm{pH}$ modifiers was not necessary. This presented an additional advantage, and it was that the negatively charged $\mathrm{CuO} N P s$ (zeta potential values between $-15 \mathrm{mV}$ and $-25 \mathrm{mV}$ ) should resist aggregation through interparticle electrostatic repulsion.

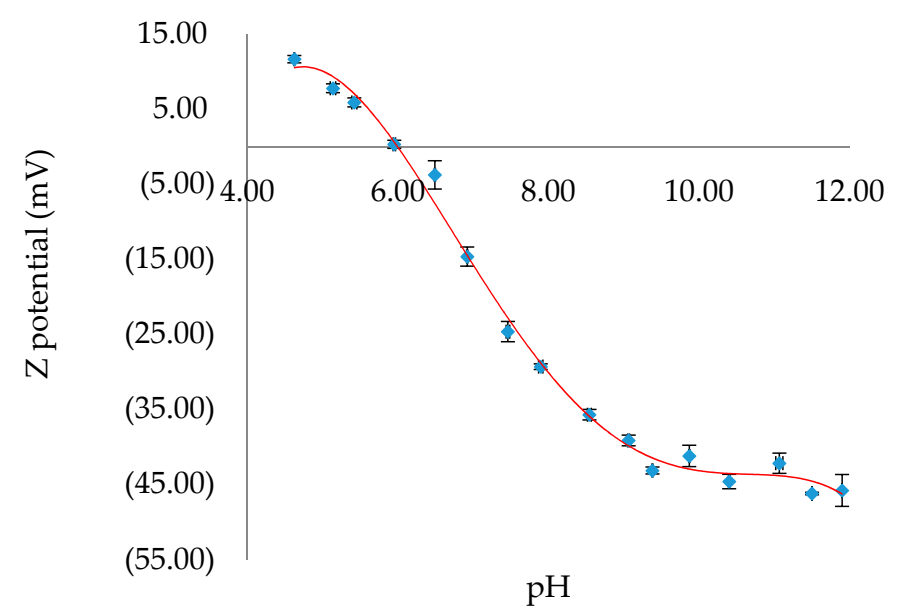

Figure 8. Variation of the $\mathrm{Z}$ potential of $\mathrm{CuO}$ NPs with $\mathrm{pH}$. The values of $\mathrm{Z}$ potential were given as mean $\pm \mathrm{SD}$ of triplicate samples. The best fit trend line in red. 
Dependence of the fluorescence intensity of $\mathrm{H}_{2} \mathrm{SB}$ in an 80:20 ethanol-water mixture at $100 \mu \mathrm{M}$ concentration with addition of $\mathrm{CuO} N P s$ in suspension $(100 \mu \mathrm{M})$ has been studied. Spectral data were recorded after the addition of CuO NPs $(0.00 \mathrm{~mL}, 0.01 \mathrm{~mL}, 0.02 \mathrm{~mL}, 0.03 \mathrm{~mL}, 0.04 \mathrm{~mL}, 0.05 \mathrm{~mL}, 0.06 \mathrm{~mL}$, $0.07 \mathrm{~mL}, 0.08 \mathrm{~mL}, 0.09 \mathrm{~mL}$ and $0.1 \mathrm{~mL})$ to $\mathrm{H}_{2} \mathrm{SB}(1.0 \mathrm{~mL})$. The total volume of $3 \mathrm{~mL}$ has been achieved by adding the corresponding volume of an 80:20 ethanol-water mixture. No $\mathrm{pH}$ modifiers were added to attain a pH of about 7.0. The fluorescence intensity of $\mathrm{H}_{2} \mathrm{SB}$ at about $500 \mathrm{~nm}$ linearly decreased with increasing concentrations of $\mathrm{CuO}$ NPs below $0.26 \mathrm{mg} / \mathrm{L}$ of $\mathrm{CuO} \mathrm{NPs}$, declining by about $55 \%$ at $\mathrm{pH}$ 7.0 (Figure 9). The limits of detection $(\mathrm{LOD}=3 \mathrm{SD} / \mathrm{m})$ and quantification $(\mathrm{LOQ}=10 \mathrm{SD} / \mathrm{m})$ of $\mathrm{CuO}$ NPs were $9.8 \mu \mathrm{gL}^{-1}$ and $32.6 \mu \mathrm{gL}^{-1}$, respectively. It must be noted that these values are lower than those previously reported by us for a pyrrole-based Schiff base ligand $\left(13.83 \mu \mathrm{gL}^{-1}\right.$ and $46.05 \mu \mathrm{gL}^{-1}$, respectively) [19].

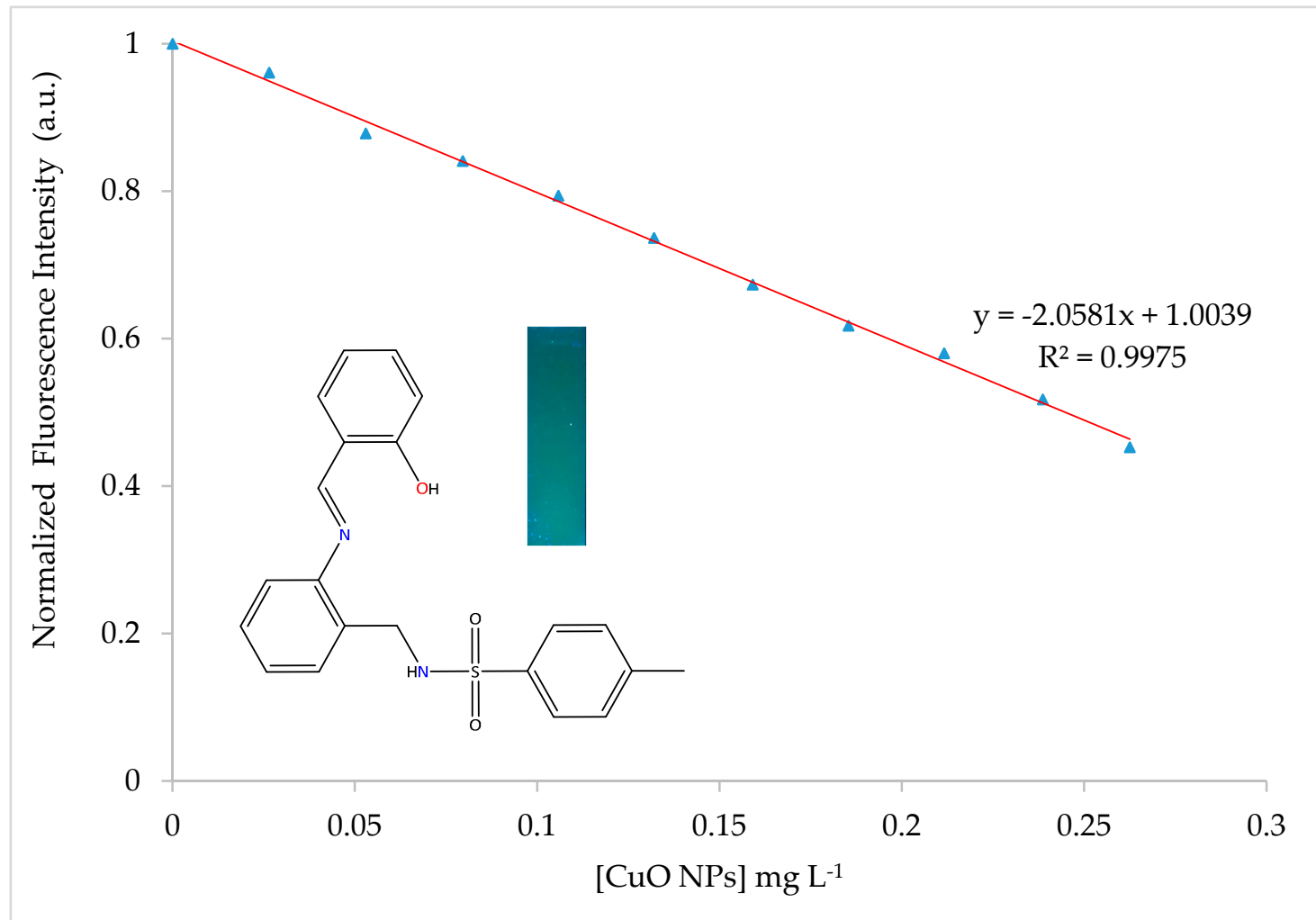

Figure 9. Variation of the fluorescence intensity of $\mathrm{H}_{2} \mathrm{SB}$ with concentration of $\mathrm{CuO}$ NPs. A fluorescent photographic image under UV lamp ( $365 \mathrm{~nm}$ ) obtained for the blue-emitting $\mathrm{H}_{2} \mathrm{SB}$ has been included.

The quenching mechanism upon titration with $\mathrm{CuO}$ NPs was studied with Stern-Volmer plots [29] $\left(\mathrm{I}_{0} / \mathrm{I}=1+\mathrm{K}_{\mathrm{SV}}\right.$ [quencher]) (Figure S5). According to the slope, the value of the quenching constant $\left(\mathrm{K}_{\mathrm{SV}}\right)$ for $\mathrm{H}_{2} \mathrm{SB}$-coated $\mathrm{CuO}$ NPs is found to be $17.510^{3} \mathrm{M}^{-1}$ at $20^{\circ} \mathrm{C}, 9.410^{3} \mathrm{M}^{-1}$ at $30^{\circ} \mathrm{C}$ and $6.710^{3} \mathrm{M}^{-1}$ at $40^{\circ} \mathrm{C}$. A static quenching mechanism has been deduced from the decrease of quenching efficiency with increasing temperature. Quenching has occurred as a result of the formation of a non-fluorescent ground-state complex through electrostatic attraction, which supports the binding of $\mathrm{H}_{2} \mathrm{SB}$ on $\mathrm{CuO}$ NPs surfaces.

Studying the effect on the fluorescence intensity of the time elapsed after addition of $\mathrm{CuO}$ NPs upon a solution of $\mathrm{H}_{2} \mathrm{SB}$, we have deduced that the ligand can interact with the surface of $\mathrm{CuO} N P s$ in about 2 minutes (Figure S6). The selectivity of $\mathrm{H}_{2} \mathrm{SB}$ as a fluorescence receptor for $\mathrm{CuO}$ NPs was tested in the presence of some other widely used nanomaterials, such as $\mathrm{TiO}_{2}, \mathrm{Cu}, \mathrm{Ag}$ and $\mathrm{Au}$ (Figure S7). As a criterion for interference, $\mathrm{a} \pm 10 \%$ variation of the average fluorescence intensity was used. These results showed that $\mathrm{TiO}_{2}, \mathrm{Ag}$ and $\mathrm{Au}$ NPs at the same molar concentration as $\mathrm{CuO}$ NPs do not 
interfere with its determination, although $\mathrm{Cu}$ NPs can interfere. This could be due to the rapid surface oxidation of $\mathrm{Cu}$ NPs [30], behaving then as CuO NPs.

\section{Conclusions}

Crystal structures of $\mathrm{Ni}(\mathrm{HSB})_{2}, \mathrm{Pd}(\mathrm{HSB})_{2}$ and $\mathrm{Cu}(\mathrm{HSB})_{2}$ have been elucidated by using single crystal X-ray diffraction techniques, showing that $\mathrm{H}_{2} \mathrm{SB}$ is acting as a monoanionic bidentate $\mathrm{O}, \mathrm{N}$-donor chelating ligand. The determination of the corresponding binding constants by fluorescence quenching showed that affinity of $\mathrm{H}_{2} \mathrm{SB}$ to $\mathrm{Cu}^{2+}$ is higher than for $\mathrm{Ni}^{2+}$ and $\mathrm{Pd}^{2+}$. The arrangement of the ligand in the three complexes is so similar that they are practically superimposable, indicating a very stable conformation in the solid state. By contrast, a conformational study on $\mathrm{Pd}(\mathrm{HSB})_{2}$ using 2D NMR spectroscopy showed the presence of two conformers in solution, both with an $E$ configuration of the ligand.

$\mathrm{H}_{2} \mathrm{SB}$ interacts with increasing concentrations of $\mathrm{Cu}^{2+}$ ions in absence of $\mathrm{pH}$ modifiers, at room temperature, and in a short time, which gives rise to a linear increase in the absorbance of a band centered at about $392 \mathrm{~nm} . \mathrm{H}_{2} \mathrm{SB}$ possesses selectivity toward $\mathrm{Cu}^{2+}$ in the presence of the most common metal ions in water $\left(\mathrm{Na}^{+}, \mathrm{K}^{+}, \mathrm{Ca}^{2+}, \mathrm{Mg}^{2+}, \mathrm{Al}^{3+}\right.$ and $\left.\mathrm{Fe}^{3+}\right)$ and some heavy transition metal ions, such as the soft acids $\mathrm{Pd}^{2+}$ and $\mathrm{Cd}^{2+}$. Unfortunately, other borderline acids (such as $\mathrm{Ni}^{2+}, \mathrm{Co}^{2+}$ and $\mathrm{Zn}^{2+}$ ) could interfere in the determination of $\mathrm{Cu}^{2+}$ ions.

The fluorescence intensity of $\mathrm{H}_{2} \mathrm{SB}$ in ethanol:water solutions $(80: 20 \mathrm{v} / \mathrm{v})$ shows a linear variation with the concentration of $\mathrm{CuO} N P s$ in the range $0-0.26 \mathrm{mg} / \mathrm{L}$, decreasing by about $55 \%\left(\lambda_{\mathrm{em}}=500 \mathrm{~nm}\right.$, $\lambda_{\text {ex }}=390 \mathrm{~nm}$ ). LOD and LOQ were $9.8 \mathrm{mg} / \mathrm{L}$ and $32.6 \mathrm{mg} / \mathrm{L}$, respectively. $\mathrm{TiO}_{2}, \mathrm{Ag}$ and $\mathrm{Au} \mathrm{NPs} \mathrm{can}$ be tolerated without interference at concentrations of $100 \mu \mathrm{M}$. In view of the effect of temperature, according to Stern-Volmer plots, quenching has occurred as a result of the formation of a non-fluorescent ground-state surface complex $\mathrm{H}_{2} \mathrm{SB}-\mathrm{CuO}$ NPs.

Supplementary Materials: Supplementary crystallographic data for this paper have been deposited at Cambridge Crystallographic Data Center (CCDC 1563225, 1563226 and 1906115) and can be obtained free of charge via www.ccdc.cam.ac.uk/conts/retrieving.html. The following information is available online at http://www.mdpi. com/2073-4352/10/3/235/s1, Tables S1-S4: Diffraction data for Ni(HSB $)_{2}, \mathrm{Pd}(\mathrm{HSB})_{2}$ and $\mathrm{Cu}(\mathrm{HSB})_{2}$, Figures S1 and S2: Molecular structures of $\mathrm{Pd}(\mathrm{HSB}) 2$ and $\mathrm{Ni}(\mathrm{HSB}) 2$, Figure S3: 2 D COSY spectrum of $\mathrm{Pd}(\mathrm{HSB})_{2}$, Figure S4: Benesi-Hildebrand plot from fluorescence titration data of $\mathrm{H} 2 \mathrm{SB}(100 \mu \mathrm{M})$ with $\mathrm{Pd}^{2+}, \mathrm{Ni}^{2+}$ and $\mathrm{Cu}^{2+}$, Figure S5: Fluorescence spectrum of $\mathrm{H} 2 \mathrm{SB}$ and plot of the intensities of the fluorescence spectra vs the concentration of $\mathrm{CuO}$ NPs at 293, 303 and 313K, Figure S6: Plot of the intensity fluorescence vs time elapsed after the addition of CuO NPs to $\mathrm{H}_{2} \mathrm{SB}$ and Figure S7: Fluorescence responses of $\mathrm{H}_{2} \mathrm{SB}$ toward a suspension of CuO NPs in the presence of $\mathrm{TiO}_{2}, \mathrm{Cu}, \mathrm{Ag}$ and $\mathrm{Au}$ NPs.

Author Contributions: Conceptualization, J.S.-M.; methodology, M.Z.-J. and M.A.-S.; software, A.G.-D., J.S.-M., and M.Z.-J.; validation, J.S.-M. and A.G.-D.; formal analysis, M.F.; investigation, M.Z.-J.; resources, J.S.-M. and P.B.-B.; data curation, M.F.; writing-original draft preparation, J.S.-M; writing-review and editing, J.S.-M. and A.G.-D.; visualization, M.F.; supervision, J.S.-M., P.B.-B. and M.A.-S.; project administration, P.B.-B.; funding acquisition, P.B.-B. All authors have read and agreed to the published version of the manuscript.

Funding: This research was funded by the Ministerio de Ciencia, Innovación y Universidades of Spain and Unión Europea (Fondo europeo de desarrollo regional) Ref. RTI2018-099222-B-I00; Dirección Xeral de I+D-Xunta de Galicia, Grupos de Referencia Competitiva (Ref. ED431C2018/19) and Strategic Grouping in Materials AEMAT (ED431 E2018/0).

Conflicts of Interest: The authors declare no conflict of interest.

\section{References}

1. Kato, T.; Nakamur, S.; Mirita, M. Determination of nickel, copper, zinc, silver, cadmium and lead in seawater by isotope dilution inductively coupled plasma mass spectrometry. Anal. Sci. 1990, 6, 623-626. [CrossRef]

2. Zhang, Y.J.; He, X.P.; Hu, M.; Li, Z.; Shi, X.X.; Chen, G.R. Highly optically selective and electrochemically active chemosensor for copper(II) based on triazole-linkedglucosyl anthraquinone. Dyes Pigment 2011, 88, 391-395. [CrossRef]

3. Wu, S.; Liu, S. A new water-soluble fluorescent $\mathrm{Cu}(\mathrm{II})$ chemosensor based on tetrapeptide histidyl-glycyl-glycyl-glycine (HGGG). Sens. Actuators B 2009, 141, 187-191. [CrossRef] 
4. Xu, Z.; Yoon, J.; Spring, D.R. A selective and ratiometric $\mathrm{Cu}^{2+}$ fluorescent probe based on naphthalimide excimer-monomer switching. Chem. Commun. 2010, 46, 2563-2565. [CrossRef]

5. Zhang, J.F.; Zhou, Y.; Yoon, J.; Kim, Y.; Kim, S.J.; Kim, J.S. Naphthalimide modified rhodamine derivative: Ratiometric and selective fluorescent sensor for $\mathrm{Cu}^{2+}$ based on two different approaches. Org. Lett. 2010, 12, 3852-3855. [CrossRef] [PubMed]

6. Hu, B.; Su, Q.; Lu, P.; Wang, Y. BODIPY modified 9-cycloheptatrienylidene fluorenederivatives: Fluorescent turn-on for detecting $\mathrm{Cu}^{2+}$ with acidity independence. Sens. Actuators B 2012, 168, 310-317. [CrossRef]

7. Gunnlaugsson, T.; Leonard, J.P.; Murray, N.S. Highly selective colorimetric naked-eye Cu(II) detection using an azobenzene chemosensor. Org. Lett. 2004, 6, 1557-1560. [CrossRef] [PubMed]

8. Kaur, P.; Sareen, D.; Singh, K. Selective colorimetric sensing of $\mathrm{Cu}^{2+}$ using triazolyl monoazo derivative. Talanta 2011, 83, 1695-1700. [CrossRef]

9. Maity, D.; Govindaraju, T. Highly selective visible and near-IR sensing of $\mathrm{Cu}^{2+}$ based on thioureasalicylaldehyde coordination in aqueous media. Chem. Eur. J. 2011, 17, 1410-1414. [CrossRef]

10. Sheng, R.; Wang, P.; Gao, Y.; Wu, Y.; Liu, W.; Ma, J.; Li, H.; Wu, S. Colorimetric test kit for $\mathrm{Cu}^{2+}$ detection. Org. Lett. 2008, 10, 5015-5018. [CrossRef]

11. Hrishikesan, E.; Saravanan, C.; Kannan, P. Bis-triazole-appended azobenzene chromophore for selective sensing of copper(II) ion. Ind. Eng. Chem. Res. 2011, 50, 8225-8229. [CrossRef]

12. Cui, M.-H.; Liu, Q.; Fei, Q.; Fei, Y.-Q.; Liu, Y.-M.; Shan, H.-Y.; Feng, G.-D.; Huan, Y.-F. A novel UV-visible chemosensor based on the 8-hydroxyquinoline derivative for copper ion detection. Anal. Methods 2015, 7, 4252-4256. [CrossRef]

13. Laborda, F.; Bolea, E.; Cepria, G.; Gómez, M.T.; Jiménez, M.S.; Pérez-Arantegui, J.; Castillo, J.R. Detection, characterization and quantification of inorganic engineered nanomaterials: A review of techniques and methodological approaches for the analysis of complex samples. Anal. Chim. Acta 2016, 904, 10-32. [CrossRef] [PubMed]

14. Yan, A.; Chen, Z. Detection methods of nanoparticles in plant tissues. In New Visions in Plant Science; Çelik, Ö., Ed.; Intechopen: London, UK, 2018; Chapter 6.

15. Navratilova, J.; Praetorius, A.; Gondikas, A.; Fabienke, W.; Kammer, F.; Hofmann, T. Detection of engineered copper nanoparticles in soil using single particle ICP-MS. Int. J. Environ. Res. Public Health 2015, 12, 15756-15768. [CrossRef]

16. Chatterjee, A.; Santra, M.; Won, N.; Kim, S.; Kim, J.K.; Kim, S.B.; Ahn, K.H. Selective fluorogenic and chromogenic probe for detection of silver ions and silver nanoparticles in aqueous media. J. Am. Chem. Soc. 2009, 131, 2040-2041. [CrossRef]

17. Cayuela, A.; Soriano, M.L.; Valcárcel, M. Reusable sensor based on functionalized carbon dots for the detection of silver nanoparticles in cosmetics via inner filter effect. Anal. Chim. Acta 2015, 872, 70-76. [CrossRef]

18. Rebe Raz, S.; Leontaridou, M.; Bremer, M.G.E.G.; Peters, R.; Weigel, S. Development of surface plasmon resonance-based sensor for detection of silver nanoparticles in food and the environment. Anal. Bioanal. Chem. 2012, 403, 2843-2850. [CrossRef]

19. Sanmartín-Matalobos, J.; García-Deibe, A.M.; Fondo, M.; Zarepour-Jevinani, M.; Domínguez-González, M.R.; Bermejo-Barrera, P. Exploration of an easily synthesized fluorescent probe for detecting copper in aqueous samples. Dalton Trans. 2017, 46, 15827-15835. [CrossRef]

20. Sanmartín, J.; Novio, F.; García-Deibe, A.M.; Fondo, M.; Bermejo, M.R. Trimorphism of an asymmetric disulfonamide Schiff base. New J. Chem. 2007, 31, 1605-1612. [CrossRef]

21. Sanmartín-Matalobos, J.; Fondo, M.; Alves-Iglesias, Y.; Aboal-Somoza, M.; Bermejo-Barrera, P.; García-Deibe, A.M. Taking advantage of the coordinative behavior of a tridentate schiff base ligand towards $\mathrm{Pd}^{2+}$ and $\mathrm{Cu}^{2+}$. Crystals 2019, 9, 407. [CrossRef]

22. Sheldrick, G.M. SADABS, Area-Detector Absorption Correction; Siemens Industrial Automation, Inc.: Madison, WI, USA, 2001.

23. Sheldrick, G.M. SHELXT-Integrated space-group and crystal-structure determination. Acta Cryst. 2015, A71, 3-8. [CrossRef]

24. Sheldrick, G.M. Crystal structure refinement with SHELXL. Acta Cryst. 2015, C71, 3-8. 
25. Van Beijnen, A.J.M.; Nolte, R.J.M.; Naaktgeboren, A.J.; Zwikker, J.W.; Drenth, W. Helical configuration of poly(iminomethylenes). Synthesis and CD spectra of polymers derived from optically active isocyanides. Macromolecules 1983, 16, 1679-1689.

26. Kim, H.M.; Jung, C.; Kim, B.R.; Jung, S.-Y.; Hong, J.H.; Ko, Y.-G.; Lee, K.J.; Cho, B.R. Environment-sensitive two-photon probe for intracellular free magnesium ions in live tissue. Angew. Chem. Int. Ed. 2007, 46, 3460-3463. [CrossRef] [PubMed]

27. Yu, S.; Liu, J.; Yin, Y.; Shen, M. Interactions between engineered nanoparticles and dissolved organic matter: A review on mechanisms and environmental effects. J. Environ. Sci. 2018, 63, 198-217. [CrossRef]

28. Philippe, A.; Schaumann, G.E. Interactions of dissolved organic matter with natural and engineered inorganic colloids: A review. Environ. Sci. Technol. 2014, 48, 8946-8962. [CrossRef]

29. Lakowicz, J.R. Principles of Fluorescence Spectroscopy, 3rd ed.; Springer Nature: Basel, Switzerland, 2006.

30. Hedberg, Y.S.; Pradhan, S.; Cappellini, F.; Karlsson, M.-E.; Blomberg, E.; Karlsson, H.L.; Odnevall Wallinder, I.; Hedberg, J.F. Electrochemical surface oxide characteristics of metal nanoparticles $(\mathrm{Mn}, \mathrm{Cu}$ and $\mathrm{Al})$ and the relation to toxicity. Electrochim. Acta 2016, 212, 360-371. [CrossRef]

(C) 2020 by the authors. Licensee MDPI, Basel, Switzerland. This article is an open access article distributed under the terms and conditions of the Creative Commons Attribution (CC BY) license (http://creativecommons.org/licenses/by/4.0/). 